\title{
Wyznaczanie priorytetów rozwoju społeczno-gospodarczego jako celowościowa determinanta działalności podmiotów sektora MŚP (ujęcie publicznoprawne)
}

\author{
Establecimiento de las prioridades para el desarrollo \\ socioeconómico como determinante objetiva \\ de la actividad de las entidades del sector de las pymes \\ (enfoque de derecho público)
}

Katarzyna Kokocińska

Uniwersytet im. Adama Mickiewicza w Poznaniu

\section{Prawo w przestrzeni społeczno-gospodarczej. Wprowadzenie}

Rolę prawa w przestrzeni gospodarczej wyznacza obowiązujący system gospodarczy będący wynikiem przyjętych reguł, zasad i wartości decydujących o dopuszczalnej intensywności oddziaływania władzy publicznej na stosunki społeczno-gospodarcze. Prawo jest instrumentem realizacji przyjętych celów społecznych i gospodarczych ustalonych przez organy władzy publicznej prowadzące politykę (polityka państwa) na rzecz rozwojuํ. Przede wszystkim powinno ono służyć tworzeniu warunków sprzyjających funkcjonowaniu konkurencyjnej i nowoczesnej gospodarki rynkowej. Jak wskazuje K. Strzyczkowski, „prawo stanowi najbardziej przydatny i nieodzowny instrument sterowania gospodarką"2, co należy traktować jako dopuszczalną ingerencję władzy publicznej w stosunki gospodarcze dla osiągnięcia przyjętych celów, które nie zawsze ograniczają się do tworzenia warunków i zapewnienia niezakłóconego funkcjonowania mechanizmów rynkowych.

Ramowy porządek prawny, który gwarantuje podstawowe prawa i wolności gospodarcze (funkcja organizująca regulacji prawnej3), wypełniają coraz częściej działania o charakterze motywującym do podjęcia określonych zachowań, uzupełniające,

${ }^{1}$ Zob. K. Kokocińska, Prawny mechanizm prowadzenia polityki rozwoju $w$ zdecentralizowanych strukturach władzy publicznej, Poznań 2014, s. 309.

${ }^{2}$ K. Strzyczkowski, Prawo gospodarcze publiczne, wyd. 6, Warszawa 2011, s. 39.

${ }^{3}$ Tamże, s. 40 i nast. 
a często zastępujące mechanizmy wolnej konkurencji. Uzasadnieniem tej sytuacji jest potrzeba osiągania istotnych celów publicznych wynikających z aktualnej polityki publicznej, prowadzonej na poziomie unijnym bądź krajowym. W doktrynie publicznego prawa gospodarczego coraz częściej podkreśla się, że stosowanie przez państwo (władzę publiczną) instrumentów wspierania ukierunkowuje uczestników rynku na realizację celów motywowanych interesem publicznym ${ }^{4}$. Publiczny aspekt celów i środków, a także osiąganych efektów, wskazuje na szczególny charakter funkcji wspierania gospodarczego skutkującej przenoszeniem przez państwo (organ wspierający) celów ogólnych o publicznym charterze na cele indywidulane poszczególnych przedsiębiorców, którzy korzystają ze wsparcia ${ }^{5}$.

Instrumenty prawne o charakterze wspierającym (motywującym) tworzą zespół zachęt do podejmowania przez przedsiębiorców określonej aktywności, zgodnej z polityką społeczno-gospodarczego rozwoju państwa. W konsekwencji państwo (czy w szerszym zakresie - Unia Europejska) za pomocą zróżnicowanych instrumentów prawnych stymuluje uczestników rynku do osiągnięcia przyjętych celów społeczno-gospodarczych. Działania te (a także polityka władz publicznych) nie powinny jednak skutkować zmianą stosunków społeczno-gospodarczych ugruntowanego systemu gospodarczego, który konstruują normy traktatowe oraz normy konstytucyjne. Powinny być osadzone w aktualnym kontekście społeczno-gospodarczym, który wyznaczają przede wszystkim, oprócz gwarantowanych wolności i praw ekonomicznych, konstytucyjne zasady ustroju społeczno-gospodarczego, a w szczególności zasada „społecznej gospodarki rynkowej” przesądzająca zarówno o ustroju gospodarczym Unii Europejskiej, jak i o modelu krajowej gospodarki.

Ustrój społecznej gospodarki rynkowej był przedmiotem szerokich badań naukowych i analizy doktryny publicznego prawa gospodarczego ${ }^{6}$. I choć nie wypraco-

${ }^{4}$ Zob. K. Horuski, \$ 30. Wspieranie gospodarki, w: System Prawa Administracyjnego, t. 8A, Publiczne prawo gospodarcze, red. R. Hauser, Z. Niewiadomski, A. Wróbel, Warszawa 2012, s. 753 i cytowana tam literatura.

${ }^{5}$ K. Strzyczkowski, Prawo gospodarcze..., s. 191.

${ }^{6}$ Zob. m.in.: A. Adamczyk, Definicja i istota społecznej gospodarki rynkowej, w: Społeczna gospodarka rynkowa, red. R.W. Włodarczyk, Warszawa 2010; T. Kocowski, Reglamentacja forma interwencjonizmu państwowego w społecznej gospodarce rynkowej, w: Państwo i rynek. Obszary zawodności, red. U. Kalina-Prasznic, Wrocław 2011; C. Kosikowski, Publiczne prawo gospodarcze Polski i Unii Europejskiej, Warszawa 2007, s. 35-36; G. Przesławska, Społeczna gospodarka rynkowa, w: Regulowana gospodarka rynkowa, red. U. Kalina-Prasznic, Kraków 2003; P. Pysz, Społeczna gospodarka rynkowa. Ordoliberalna koncepcja polityki gospodarczej, Warszawa 2008; K. Strzyczkowski, Konstytucyjna zasada społecznej gospodarki rynkowej jako podstawa tworzenia i stosowania prawa, w: Zasady ustroju społecznego i gospodarczego procesie stosowania Konstytucji, red. C. Kosikowski, Warszawa 2005; tenże: Prawo gospodarcze publiczne, wyd. 4, Warszawa 2008, s. 64-71; K. Sobczak, Gospodarka rynkowa a władza publiczna, Warszawa 1997, passim; T. Włudyka, Model społecznej gospodarki rynkowej a transformacja ustrojowa polskiej gospodarki. Analiza prawnogospodarcza, Kraków 2002, passim; A. Żurawik, Zasady ogólne publicznego prawa gospodarczego, w: System Prawa Administracyjnego, t. 8A: Publiczne prawo gospodarcze, red. R. Hauser, Z. Niewiadomski, A. Wróbel, Warszawa 2013, s. 439-448 i wskazywana tam literatura; K. Kokocińska, Społeczna gospodarka rynkowa - komplementarność, równowaga czy przewaga wartości? Uwagi na tle działań państwa w zakresie prowadzenia polityki rozwoju, „Gdańskie Studia Prawnicze” 2017, nr 37, s. 27-36. 
wano jednoznacznej koncepcji, to dla prowadzonych badań istotne jest ustalenie, jakie są konsekwencje prawnie formułowanego (w art. 3 Traktatu o Unii Europejskiej ${ }^{7}$ i w art. 20 Konstytucji RP) modelu społecznej gospodarki rynkowej dla aktywności instytucji unijnych i organów władzy publicznej państwa w sferze rozwoju społeczno-gospodarczego ${ }^{8}$. W modelu, który jest oparty na samoregulującym się mechanizmie rynkowym, dopuszcza się jednak korygowanie praw rynku przez państwo w celu realizowania określonych potrzeb społecznych niemożliwych do spełnienia przy całkowicie swobodnym funkcjonowaniu praw rynkowych, ale przy jednoczesnym ich poszanowaniu9. Społeczna gospodarka rynkowa, stanowiąca podstawę ustroju gospodarczego, to nie tylko model ekonomiczny UE i państwa. Jest wyrazem konstytucyjnego obrazu ładu społecznego ${ }^{10}$ opartego na dwóch podstawowych elementach, którymi są wolność gospodarcza i własność prywatna, a także solidarność, dialog i współpraca partnerów społecznych ${ }^{11}$. Elementy te należy traktować kompleksowo i komplementarnie. Przyjęte na poziomie unijnym i krajowym przepisy prawa nie dają legitymacji do dowolnego kształtowaniu modelu, z drugiej strony nie tworzą abstrakcyjnego modelu społecznej gospodarki rynkowej, niezmiennego w czasie i zamkniętego na zmiany społeczeństwa i gospodarki ${ }^{12}$. Regulacje te należy traktować jako dyrektywy kierunkowe, określające model społeczno-gospodarczy obowiązujący w Unii Europejskiej i w Polsce poprzez wskazanie celów publicznych oraz wartości istotnych społecznie.

Obowiązujący ustrój wyznaczający stosunki społeczno-gospodarcze stanowi o kierunkach polityki społeczno-gospodarczej państwa. To polityka władzy publicznej wyra-

7 Traktat o Unii Europejskiej (wersja skonsolidowana), Dz. Urz. UE z 26.10.2012, C 326/13, dalej: TUE.

${ }^{8} \mathrm{Na}$ ten temat w szczególności: A. Domańska, Konstytucyjne podstawy ustroju gospodarczego Polski, Warszawa 2001; C. Kosikowski, Zasady ustroju społecznego i gospodarczego, w: Podstawowe problemy stosowania Konstytucji Rzeczypospolitej Polskiej, Raport wstępny, red. K. Działocha, Warszawa 2004; K. Sobczak, Gospodarka w ujęciu konstytucyjnym, „Przegląd Ustawodawstwa Gospodarczego” 1997, nr 2; K. Strzyczkowski, Konstytucyjna zasada...; Publiczne prawo gospodarcze. Zarys wykładu, red. J. Grabowski, Bydgoszcz-Katowice 2008, s. 13-14; Prawo gospodarcze. Zagadnienia administracyjnoprawne, red. H. Gronkiewicz-Waltz, M. Wierzbowski, wyd. 2 zm., Warszawa 2011, s. 42-52.

${ }^{9}$ Wyrok Trybunału Konstytucyjnego z dnia 30 stycznia 2001 roku, K 17/00, OTK 2001, nr 1, poz. 4. Trybunał Konstytucyjny wskazuje, że społeczna gospodarka rynkowa ma swoje szersze podstawy niż art. 20 Konstytucji RP, podkreślając potrzebę jego odczytywania w kontekście pozostałych przepisów konstytucyjnych, w tym formułujących zasadę demokratycznego państwa prawnego i sprawiedliwości społecznej (art. 2 Konstytucji RP). W wyroku z dnia 28 stycznia 2003 roku Trybunał Konstytucyjny wskazuje na konieczność dokonywania interpretacji art. 20 Konstytucji RP z uwzględnieniem europejskiego standardu określającego, jaka jest zasada interpretacji przyjaznej prawu europejskiemu, K 2/02, OTK-A 2003, nr 1, poz. 4. Por. wyrok TK z 28 marca 2000 roku, K 27/99, OTK 2000, nr 2, poz. 62; na ten temat: K. Kiczka, Konstytucjonalizacja publicznego prawa gospodarczego, w: Nowe problemy badawcze $w$ teorii publicznego prawa gospodarczego ( $z$ uwzględnieniem samorzadu terytorialnego), red. L. Kieres, Wrocław 2010; A. Żurawik, dz. cyt., s. 445-448.

${ }^{10}$ C. Banasiński, Konstytucyjne podstawy ustroju gospodarczego, w: Prawo gospodarcze. Zagadnienia administracyjnoprawne, wyd. 2, red. H. Gronkiewicz-Waltz, M. Wierzbowski, Warszawa 2011, s. 42.

${ }^{11}$ Według J. Bocia wyliczenie to nie ma charakteru wyczerpującego. J. Boć, Konstytucje Rzeczypospolitej oraz komentarz do Konstytucji RP z 1997 roku, Wrocław 1998, s. 51.

${ }^{12}$ C. Banasiński, Konstytucyjne podstawy ustroju..., s. 49. 
żona ostatecznie treścią aktów normatywnych rozstrzyga o stopniu natężenia aspektów społecznych i gospodarczych. Rozstrzyga o jej progospodarczym lub prospołecznym wymiarze. Prawo odgrywa zatem „rolę aktywnego instrumentu realizacji celów społecznych i gospodarczych [...], konstytuuje określony ład społeczny i gospodarczy ${ }^{13}$, wypełniając formułę społecznej gospodarki rynkowej w zależności od potrzeb” ${ }^{\prime 14}$.

\section{Planowanie społeczno-gospodarczego rozwoju Unii Europejskiej $\mathrm{z}$ uwzględnieniem potencjału sektora MŚP}

Potrzeby społeczne i gospodarcze, wyznaczane celami polityki społeczno-gospodarczej UE i państw członkowskich, są wyrażane w uchwalanych okresowo (w określonej perspektywie czasowej) aktach polityki władzy wykonawczej - strategiach rozwoju, politykach publicznych, planach, w tym planach rozwojowych, i programach. Przyjmowane akty polityki społeczno-gospodarczej ${ }^{15}$ wskazują między innymi cele i priorytety działań oraz stopień i kierunki ingerencji państwa w obszarze rozwoju i spójności, będąc nie tylko wyrazem kierunków reform, ale też punktem odniesienia dla działalności organów administracji publicznej odpowiedzialnych za realizację polityki rozwoju. W dobie europeizacji cele polityki krajowej są wyrazem ogólnych kierunków przemian społeczno-gospodarczych wynikających z aktualnych idei i koncepcji odnoszących się do gospodarki i życia społecznego, realizowanych współcześnie $\mathrm{w}$ skali globalnej ${ }^{16}$. Planowanie działań podmiotów władzy publicznej, które powinny znaleźć odniesienie w regulacjach normatywnych, zapewnia stabilność stosunków społeczno-gospodarczych i pewność dla uczestników obrotu gospodarczego. Jest to szczególnie widoczne $\mathrm{w}$ dobie aktualnych przemian i kryzysu wywołanego między innymi epidemią COVID-19, w którym instytucje unijne i krajowe organy władzy publicznej powinny reagować w tych obszarach, w których ich wsparcie jest konieczne, zarówno poprzez zaspokajanie podstawowych potrzeb, jak i poprzez mobilizowanie do działania, stymulując rozwój społeczno-gospodarczy.

${ }^{13}$ K. Strzyczkowski, Prawo gospodarcze..., s. 39.

${ }^{14}$ C. Banasiński, Konstytucyjne podstawy ustroju..., s. 49, tenże: Konstytucyjne podstawy porządku prawnego w gospodarce, w: Konstytucja. Trybunał Konstytucyjny, red. C. Banasiński, J. Oniszczuk, Warszawa 1998, s. 16; a także na temat ustroju gospodarczego: T. Rabska, Gospodarka rynkowa i jej zasady, w: Konstytucja i gospodarka, wybór i opracowanie P. Kaczanowski, Warszawa 1995, s. 80; A. Szmyt, O normowaniu podstaw ustroju gospodarczego Rzeczypospolitej Polskiej, „Gdańskie Studia Prawnicze”, t. 5, 1999, s. 403; Zasady ustroju społecznego i gospodarczego w procesie stosowania Konstytucji, red. C. Kosikowski, Warszawa 2005; K. Kiczka, Funkcje administracji gospodarczej jako przedmiot badań, w: Funkcje współczesnej administracji gospodarczej, red. B. Popowska, Poznań 2006, s. 56-59; tenże, Uwagi o wolności działalności gospodarczej, w: Księga Jubileuszowa Profesora S. Jędrzejewskiego, Toruń 2009, s. 231-234.

${ }^{15}$ W Polsce przyjmowane na podstawie reguł wynikających z Ustawy z dnia 6 grudnia $2006 \mathrm{r}$. o zasadach prowadzenia polityki i rozwoju (t.j.: Dz. U. 2019 poz. 1295, 2020, z 2020 r. poz. 1378, 2327); szerzej na ten temat: K. Kokocińska, Prawny mechanizm..., s. 309.

${ }^{16}$ Szerzej: J. Buzek, A. Surdej, Odrodzenie ducha - budowa wolności. Perspektywa rozwoju gospodarki solidarnej, „Ruch Prawniczy, Ekonomiczny i Socjologiczny” 2010, z. 4, s. 5-20. 
Założenia społecznego i gospodarczego wymiaru wspólnego rynku Unii Europejskiej, którego istota opiera się na zrównoważonym wzroście, społecznej gospodarce rynkowej o wysokiej konkurencyjności zmierzającej do pełnego zatrudnienia i postępu społecznego oraz na wysokim poziomie ochrony i poprawy jakości środowiska naturalnego ${ }^{17}$, znajduje odniesienie we współczesnej wizji Europy. Europa rozpoczyna proces transformacji prowadzącej do neutralności klimatycznej i przywództwa cyfrowego. Przyjęta „Nowa strategia przemysłowa dla Europy”"18 zakładająca transformację ekologiczną i cyfrową, której zakres wdrażania oraz charakter planowanych działań to konsekwentna realizacja polityki unijnej zdefiniowanej w programie strategicznym Rady Europejskiej na lata 2019-2024 Europejski Zielony Ład ${ }^{19}$, oraz strategia „Kształtowanie cyfrowej przyszłości Europy” ${ }^{20}$ wyznaczają cele oraz kierunek zmian nowej polityki przemysłowej, skupiającej się na rozwiązaniu problemów związanych z klimatem i środowiskiem naturalnym. Polityka ta jest oparta na silnej podbudowie wartości europejskiej społecznej gospodarki rynkowej: konkurencji, otwartym rynku, wysokim poziomie badań i technologii oraz na silnym jednolitym rynku, na którym eliminuje się bariery i ogranicza biurokrację. Podkreślana ochrona, zachowanie i poprawa kapitału naturalnego UE oraz ochrona zdrowia i dobrostanu obywateli przed zagrożeniami i negatywnymi skutkami związanymi ze środowiskiem są istotnymi elementami transformacji gospodarczej, która powinna przebiegać w spośób sprawiedliwy i sprzyjający włączeniu społecznemu. Sformułowane w Europejskim Zielonym Ładzie ambitne cele klimatyczne UE na lata 2030 i 2050 (w tym osiągnięcie neutralności klimatycznej do 2050 r. ${ }^{21}$ ) stanowiły podstawę

${ }^{17}$ Art. 3 ust. 3 Traktatu o Unii Europejskiej stanowi: „Unia ustanawia rynek wewnętrzny. Działa na rzecz trwałego rozwoju Europy, którego podstawą jest zrównoważony wzrost gospodarczy oraz stabilność cen, społeczna gospodarka rynkowa o wysokiej konkurencyjności zmierzająca do pełnego zatrudnienia i postępu społecznego oraz wysoki poziom ochrony i poprawy jakości środowiska. Wspiera postęp naukowo-techniczny. Zwalcza wykluczenie społeczne i dyskryminację oraz wspiera sprawiedliwość i ochronę socjalną, równość kobiet i mężczyzn, solidarność między pokoleniami i ochronę praw dziecka. Wspiera spójność gospodarczą, społeczną i terytorialną oraz solidarność między państwami członkowskimi. Szanuje swoją bogatą różnorodność kulturową i językową oraz czuwa nad ochroną i rozwojem dziedzictwa kulturowego Europy". W. Sanetra podkreśla, że przewidzianą w art. 3 ust. 3 TUE zasadę społecznej gospodarki rynkowej należy traktować jako powinność kształtowania przez państwa członkowskie gospodarek zgodnie z wymaganiami tej zasady oraz powinność instytucji unijnych podejmowania działań, które prowadzą do tego, że jest ona pełniej wcielana w życie przez te państwa, W. Sanetra, Prawo pracy po Traktacie z Lizbony, „Europejski Przegląd Sądowy”, luty 2010, s. 4.

${ }^{18}$ Communication from the Commission to the European Parliament, the Council, the European Economic and Social Committee and the Committee of the Regions - A New Industrial Strategy for Europe, Brussels, 10.3.2020, $\operatorname{COM}(2020) 102$ final.

${ }^{19}$ Communication from the Commission to the European Parliament, the Council, the European Economic and Social Committee and the Committee of the Regions - The European Green Deal, Brussels, 11.12.2019, $\operatorname{COM}(2019) 640$ final.

${ }^{20}$ Communication from the Commission to the European Parliament, the Council, the European Economic and Social Committee and the Committee of the Regions - Shaping, Europe's digital future, Brussels, 19.2.2020, $\operatorname{COM}(2020) 67$ final.

${ }^{21}$ Komunikat Komisji do Parlamentu Europejskiego, Rady, Europejskiego Komitetu Ekonomiczno-Społecznego i Komitetu Regionów: Czysta planeta dla wszystkich - Europejska długoterminowa wizja 
przygotowania nie tylko długoterminowej strategii, ale również projektu pierwszego europejskiego „prawa o klimacie”22 jako umocowania prawnego dla osiągnięcia celu neutralności klimatycznej do 2050 r. w Unii Europejskiej. Podstawową funkcją tej projektowanej regulacji prawnej jest określenie warunków transformacji. Tym samym ma ona zapewnić przewidywalność działań w ramach wszystkich polityk unijnych, które mają się przyczyniać do osiągnięcia neutralności klimatycznej. Rozpoczęte w UE w latach 1990-2018 modernizacja i transformacja gospodarki, dzięki którym Unia zmniejszyła emisję gazów, wymaga - zgodnie z zielonym przyrzeczeniem „nie szkodzić" - efektywniejszego procesu stanowienia prawa. W dokumentach strategicznych podkreśla się między innymi konieczność prowadzenia szerokich konsultacji publicznych. Uzyskuje się dzięki temu lepsze rozpoznanie wpływu na środowisko oraz skutków społecznych i gospodarczych, uwzględniając między innymi analizy oddziaływania na sektor małych i średnich przedsiębiorstw oraz czynniki ułatwiające i hamujące innowacje. Zdaniem Komisji Europejskiej oceny skutków przyczyniają się do podejmowania skutecznych decyzji politycznych jak najniższym kosztem, bowiem w ramach przeprowadzanych ocen analizuje się również spójność między prawodawstwem a nowymi priorytetami polityk unijnych ${ }^{23}$.

Wśród podstawowych elementów transformacji przemysłowej Europy, takich jak wspieranie przemysłu w przejściu na neutralność klimatyczną czy budowanie gospodarki o obiegu zamkniętym, podkreśla się konieczność stworzenia zapewnień dla przemysłu, czyli budowanie pogłębionego i bardziej scyfryzowanego jednolitego rynku. W ramach podstawowych celów zakłada się przygotowanie planu działania dotyczącego egzekwowania przepisów jednolitego rynku ${ }^{24}$, własności intelektualnej, przegląd i dostowania unijnych reguł konkurencji oraz przyjęcie regulacji prawnej odnoszącej się do usług cyfrowych służącej aktualizacji i wzmocnieniu ram prawnych jednolitego rynku usług cyfrowych. Dla realizacji tych działań niezbędne jest uwzględnienie znaczenia sektora MŚP, co jest widoczne w podejściu unijnych instytucji „MŚP dla MŚP”. Podkreślając znaczenie zaawansowanych technologicznie MŚP, które mogą pomóc dużym przedsiębiorcom w dostosowaniu modeli biznesowych i wprowadzeniu nowych form pracy odpowiednich dla epoki cyfrowej,

strategiczna dobrze prosperującej, nowoczesnej, konkurencyjnej i neutralnej dla klimatu gospodarki, Bruksela, 28.11.2018, COM (2018) 773.

${ }^{22}$ Zmieniony wniosek Komisji Europejskiej Rozporządzenie Parlamentu Europejskiego i Rady w sprawie ustanowienia ram na potrzeby osiągnięcia neutralności klimatycznej i zmieniające rozporządzenie (UE) 2018/1999 (Europejskie prawo o klimacie); Bruksela, 17.9.2020, COM(2020) 563 final, 2020/0036 (COD).

${ }^{23}$ Komisja Europejska zapowiedziała prace nad zwiększeniem efektywności stosowania wytycznych dotyczących lepszego stanowienia prawa w obszarze zrównoważonego rozwoju i innowacji, zapewniając, aby wszystkie inicjatywy w ramach Europejskiego Zielonego Ładu osiągnęły swoje cele w sposób jak najbardziej skuteczny i jak najmniej uciążliwy oraz były realizowane zgodnie ze złożonym zielonym przyrzeczeniem, aby „nie szkodzić”.

${ }^{24} \mathrm{~W}$ szczegóności w zakresie usuwania barier, z którymi zmagają się przedsiębiorstwa podczas sprzedaży towarów lub - w jeszcze większym stopniu - świadczenia usług transgranicznych, m.in.: większa harmonizacja podatkowa, w szczególności wprowadzenie wspólnej skonsolidowanej podstawy opodatkowania osób prawnych. 
Unia Europejska wspiera przedsiębiorstwa typu start-up w budowaniu gospodarki platform.Wyrazem tego jest przyjęta w marcu 2020 roku Strategia MŚP na rzecz zrównoważonej i cyfrowej Europy ${ }^{25}$, będąca jednym z kluczowych elementów polityki na rzecz rozwoju społeczno-gospodarczego Unii Europejskiej.

Przestrzeń wyznaczoną założeniami polityki gospodarczej Unii Europejskiej powinny jednak wypełnić, oprócz celów polityki unijnej na rzecz rozwoju MŚP, działania znajdujące odzwierciedlenie w przyjmowanych aktach normatywnych. Dlatego istotne jest ustalenie, za pomocą jakich prawnych środków polityki rozwoju społeczno-gospodarczego zarówno instytucje unijne, jak i krajowe osiągają przyjęte cele. Istotna jest także efektywność podejmowanych działań ${ }^{26}$.

\section{2. „Najpierw myśl na małą skalę” - znaczenie sektora MŚP dla zrównoważonej i cyfrowej Europy}

Aktywność gospodarcza małych i średnich przedsiębiorstw ze względu na jej dominujący charakter w Unii Europejskiej ma kluczowe znaczenie dla rozwoju gospodarki. Rozwój przedsiębiorczości z wykorzystaniem potencjału MŚP wpisuje się w unijną politykę, której celem jest zapewnienie długotrwałego i stabilnego wzrostu opartego na wiedzy ${ }^{27}$. W Komunikacie Komisji Europejskiej „Najpierw myśl na małą skalę" - Program „Small Business Act” dla Europy ${ }^{28}$ zaproponowano partnerstwo pomiędzy UE a państwami członkowskimi, które opiera się na uznaniu wiodącej roli MŚP w gospodarce Unii. Ma to skutkować długotrwałym procesem wprowadzenia kompleksowych ram polityki dla UE i jej państw członkowskich. Celem podejmowanych od 2008 roku działań jest upraszczanie, modernizacja i zróżnicowanie instrumentów służących wspieraniu MŚP. Wśród priorytetów wskazano konieczność opracowania i przyjęcia przepisów zarówno z zakresu prawa publicznego, jak i prywatnego, obejmujących cztery kluczowe obszary: prawo pomocy publicznej, prawo zamówień publicznych, zachęty dla przedsiębiorców (w tym zmniejszenie

${ }^{25}$ Communication from the Commission to the European Parliament, the Council, the European Economic and Social Committee and the Committee of the Regions - An SME Strategy for a sustainable and digital Europe, Brussels, 10.3.2020, $\operatorname{COM(2020)~} 103$ final.

${ }^{26}$ D. Radicic, G. Pugh, H. Hollanders, R. Winties, J. Fairburn, The impact of innovation support programs on small and medium enterprises innovation in traditional manufacturing industries: An evaluation for seven European Union regions, „Environment and Planning C: Government and Policy” 2015, nr 34(8).

${ }^{27}$ Communication from the Commission - EUROPE 2020. A strategy for smart, sustainable and inclusive growth, Brussels 2010, COM (2010) 2020 final. There are three underlying priorities of the strategy, expressed in the attributes of the prospective development: smart, sustainable and socially inclusive; all these elements are interrelated and reflect the envisioned social market economy in Europe of the 21st century. The goals declared there are relevant and representative for all member states; if accomplished, they are expected to enhance economic, social, and territorial cohesion and solidarity.

${ }^{28}$ Komunikat Komisji do Parlamentu Europejskiego, Rady, Europejskiego Komitetu Ekonomiczno-Społecznego i Komitetu Regionów: „Najpierw myśl na małą skalę” - Program „Small Business Act” dla Europy, $\operatorname{KOM(2008)~} 394$ wersja ostateczna, Bruksela, 25.6.2008. 
stawki VAT) oraz przepisy konstytuujące europejską spółkę prywatną działającą na podstawie jednolitych zasad w państwach członkowskich UE. Wśród postulatów zmian regulacji normatywnych odnoszących się do przedsiębiorczości - jako szczególnie istotnego, oprócz promocji przedsiębiorczości czy ułatwienia dostępu do kapitału - podkreślano konieczność zmniejszenia obciążeń regulacyjnych, w tym procedur rejestracyjnych, oraz znoszenia zakazów i nakazów między innymi w zakresie uzyskania zgód na podjęcie i prowadzenie działalności gospodarczej.

Zgodnie z podejściem zapoczątkowanym przez Komisję Europejską w 2008 roku jednym $\mathrm{z}$ kluczowych założeń realizowanych $\mathrm{w}$ ostatnich latach jest stworzenie warunków dla MŚP ułatwiających dostosowanie do wyzwań związanych z ochroną środowiska oraz funkcjonowaniem jednolitego rynku cyfrowego poprzez poprawę dostępu do finansowania. Ma to być kluczowym wsparciem MŚP w związku z wyzwaniami globalizacji i zmian klimatu ${ }^{29}$. W Komunikacie Komisji do Parlamentu Europejskiego, Rady, Europejskiego Komitetu Ekonomiczno-Społecznego i Komitetu Regionów: Plan działania na rzecz przedsiębiorczości do 2020 r. - Pobudzanie ducha przedsiębiorczości w Europie ${ }^{30}$ z 2013 roku, który nawiązuje do strategii na rzecz rozwoju UE - Strategii Europa 2020 - oraz komunikatu w sprawie polityki przemysłowej, wskazuje się na konieczność zmiany zarządzania gospodarczego na rzecz zrównoważonego rozwoju w ramach powiązanych wzajemnie gospodarek europejskich. Przywrócenie wzrostu gospodarczego i podniesienie poziomu zatrudnienia w Europie zdaniem Komisji Europejskiej jest możliwe dzięki zwiększeniu liczby przedsiębiorców ${ }^{31}$. Do tak określonej diagnozy i perspektyw rozwoju zaproponowano działania, które powinny zostać podjęte zarówno na poziomie unijnym, jak i na poziomie państw członkowskich w celu wsparcia przedsiębiorczości w Europie. Jednym z filarów, w ramach zdefiniowanych celów polityki unijnej, jest tworzenie otoczenia biznesowego wymagającego odpowiednich instrumentów prawnych. To za ich pomocą instytucje unijne i państwa członkowskie (organy administracji publicznej) ingerują w procesy gospodarcze dla osiągnięcia wyznaczonych celów społeczno-gospodarczych ${ }^{32} \mathrm{w}$ tych obszarach, które mają kluczowy charakter ze

${ }^{29}$ Komunikat Komisji do Parlamentu Europejskiego, Rady, Europejskiego Komitetu Ekonomiczno-Społecznego i Komitetu Regionów - Przegląd programu „Small Business Act” dla Europy, KOM(2011) 78 wersja ostateczna, Bruksela, 23.02.2011; Komunikat Komisji do Parlamentu Europejskiego, Rady, Europejskiego Komitetu Ekonomiczno-Społecznego i Komitetu Regionów: Sprawność regulacyjna UE, COM(2012) 746 final, Bruksela, 12.12.2012; Komunikat Komisji do Parlamentu Europejskiego, Rady, Europejskiego Komitetu Ekonomiczno-Społecznego i Komitetu Regionów: Inteligentne regulacje - odpowiedź na potrzeby małych i średnich przedsiębiorstw (COM(2013) 122 final, Bruksela, 7.03.2013.

${ }^{30}$ Komunikat Komisji do Parlamentu Europejskiego, Rady, Europejskiego Komitetu Ekonomiczno-Społecznego i Komitetu Regionów: Plan działania na rzecz przedsiębiorczości do 2020 r. - Pobudzanie ducha przedsiębiorczości w Europie, COM(2012) 795 finał, Bruksela, 9.01.2013.

${ }^{31}$ Zob. Komunikat Komisji do Parlamentu Europejskiego, Rady, Europejskiego Komitetu Ekonomiczno-Społecznego i Komitetu Regionów: W kierunku odnowy gospodarczej sprzyjającej zatrudnieniu, $\operatorname{COM}(2012) 173$ final, Bruksela, 18.4.2012.

${ }^{32}$ K. Strzyczkowski określa tę funkcję jako kierownictwo gospodarcze; K. Strzyczkowski, Prawo gospodarcze ..., s. 175 i nast. 
względu na przyjęte rezultaty. W przypadku MŚP obszarem, w którym konieczne jest podjęcie działań w celu zlikwidowania istniejących przeszkód utrudniających tworzenie i wzrost tych przedsiębiorstw, jest otwieranie nowych możliwości biznesowych w epoce cyfrowej poprzez lepsze wykorzystanie technologii informacyjno-komunikacyjnych (ICT), stanowiących kluczowe źródło wzrostu gospodarki krajowej $^{33}$. Inicjatywy unijne dotyczące „inteligentnego wykorzystania technologii informacyjnych i włączania MŚP do globalnych łańcuchów wartości w przemyśle" oraz umiejętności cyfrowych będą promować upowszechnianie technologii cyfrowych i łączenie MŚP ze światem cyfrowym.

Powyższe podejście odzwierciedlają także krótko- i długoterminowe cele unijnej polityki gospodarczej przyjętej w reakcji na kryzys spowodowany epidemią COVID-1934. Bezpośrednim skutkiem zastosowania zaproponowanych środków prawnych ma być odbudowa gospodarki, a także zwiększenie finansowania $\mathrm{w}$ długoterminowym budżecie UE na lata $2021-2027^{35} \mathrm{z}$ przeznaczeniem na określone cele $^{36}$. Zasoby będą przekazywane państwom członkowskim za pośrednictwem budżetu UE na wspieranie priorytetowych działań w zakresie inwestycji i reform w celu wzmocnienia programów finansowych mających kluczowe znaczenie dla odbudowy gospodarczej. Stanowi to uzupełnienie działań prowadzonych przez państwa członkowskie. Pakiet dopuszcza bardzo zróżnicowane środki interwencji w sferze gospodarczej, których rodzaj jest uzależniony od zakresu oraz charakteru działań. Środki oferowane w ramach instrumentów NextGenerationEU są kierowane na rzecz wsparcia państw członkowskich w wysiłkach na rzecz odbudowy, naprawy i wyjścia z kryzysu, mających na celu pobudzenie prywatnych inwestycji i wsparcie przedsiębiorstw znajdujących się w trudnej sytuacji oraz wzmocnienie najważniejszych programów UE w celu wyciągnięcia wniosków z kryzysu oraz wzmocnienia jednolitego rynku i jego odporności. Zasoby oferowane w ramach budżetu polityki spójności (Inicjatywa REACT-EU) wykorzystuje się na zapewnianie wsparcia w postaci kapitału obrotowego lub wsparcia na inwestycje dla MŚP, na inwestycje w sektorach o dużym potencjale tworzenia miejsc pracy, na wspieranie

${ }^{33}$ Y. Wang, What are the biggest obstacles to growth of SMEs in developing countries? - An empirical evidence from an enterprise survey, „Borsa Istanbul Review 2016, vol. 16, iss. 3, s. 167-176.

${ }^{34}$ Zgodnie z treścią przepisu art. 122 TFUE dopuszczalne jest wprowadzanie na czas określony instrumentów nadzwyczajnych i ich wykorzystywanie wyłącznie na potrzeby reagowania kryzysowego i środków służących odbudowie gospodarki.

${ }^{35}$ Zob. I. Musiałkowska, P. Idczak, How COVID-19 impacted the European integration processes? The case of EU Cohesion Policy and budget, w: Towards the "new normal” after COVID-19 - a post-transition economy perspective, red. E. Mińska-Struzik, B. Jankowska, Poznań 2021, s. 30-43.

${ }^{36}$ Komunikat Komisji do Parlamentu Europejskiego, Rady Europejskiej, Rady, Europejskiego Komitetu Ekonomiczno-Społecznego i Komitetu Regionów: Decydujący moment dla Europy: naprawa i przygotowanie na następną generację, COM(2020) 456 final, Bruksela, 27.5.2020; Komunikat Komisji do Parlamentu Europejskiego, Rady Europejskiej, Rady, Europejskiego Komitetu Ekonomiczno-Społecznego i Komitetu Regionów: Budżet UE napędza plan odbudowy Europy, $\operatorname{COM(2020)} 442$ final, Bruksela, 27.5.2020; Rozporządzenie Rady (UE) 2020/2094 z dnia 14 grudnia 2020 r. ustanawiające Instrument Unii Europejskiej na rzecz Odbudowy w celu wsparcia odbudowy w następstwie kryzysu związanego z COVID-19 (Dz. Urz. UE L 433I z 22.12.2020). 
inwestycji przyczyniających się do transformacji ku ekologicznej i cyfrowej gospodarce. Środki programu InvestEU ${ }^{37}$ będą kierowane na wspieranie celów polityki Unii poprzez operacje z zakresu finansowania i inwestycji, które przyczyniają się m.in. do konkurencyjności Unii, w tym do badań naukowych, innowacji i cyfryzacji, zrównoważonego charakteru gospodarki Unii oraz jej wymiaru środowiskowego i klimatycznego, przyczyniających się do osiągnięcia celów zrównoważonego rozwoju i celów porozumienia klimatycznego z Paryża oraz do tworzenia wysokiej jakości miejsc pracy, promowania postępu naukowego i technologicznego. Wskazuje się na konieczność zwiększania dostępu do finansowania dla MŚP, a także podnoszenia globalnej konkurencyjności takich przedsiębiorstw.

Odpowiedzią na tak zdefiniowane kierunki rozwoju oraz wyznaczone cele społeczno-gospodarcze wspólne dla Unii Europejskiej są krajowe plany odbudowy ${ }^{38}$. Kompleksowe programy reform i projektów strategicznych, służące wzmocnieniu odporności gospodarczej i społecznej oraz budowaniu potencjału gospodarek krajowych, powinny obejmować inwestycje w obszarach rozwoju kluczowych dla UE, którymi są infrastruktura, transport, energia i środowisko, innowacje, cyfryzacja, zdrowie, społeczeństwo oraz spójność terytorialna. Ich wdrożenie wymaga kompleksowego przeglądu regulacji normatywnych i odpowiedniego dostosowania do zmieniających się uwarunkowań społeczno-gospodarczych. Istotne jest jednak, że przyjmowane rozwiązania powinny zapewniać stabilność sytuacji prawnej uczestników gospodarki. Nie powinny służyć jedynie realizacji bieżącej polityki związanej $\mathrm{z}$ rozwiązywaniem doraźnych problemów $\mathrm{w}$ ramach programu wychodzenia z kryzysu i ratującego równowagę społeczno-gospodarczą, ale stanowić istotny element całościowego, długoterminowego programu obejmującego rozwój prowadzony w skali unijnej i krajowej (w tym regionalnej i lokalnej).

\section{Prawne instrumenty wspierania rozwoju sektora MŚP w Polsce}

Postulowane zmiany w podejściu do przedsiębiorczości, w tym w zakresie poprawy sytuacji prawnej przedsiębiorców z sektora MŚP, wynikające z aktów planowania gospodarczego, są ukierunkowane na wspieranie ich rozwoju. Wspieranie przed-

${ }^{37}$ Wniosek. Rozporządzenie Parlamentu Europejskiego i Rady ustanawiające Program InvestEU, COM/2020/403 final, Bruksela, 29.5.2020.

${ }^{38}$ Krajowe plany odbudowy są przyjmowane w wykonaniu obowiązku wynikającego z Rozporządzenia Parlamentu Europejskiego i Rady (UE) 2021/241 z dnia 12 lutego 2021 r. ustanawiającego Instrument na rzecz Odbudowy i Zwiększania Odporności (Dz .Urz. UE L 57 z 18.2.2021). W Polsce podstawę normatywną przygotowania i uchwalenia planu stanowi ustawa $\mathrm{z}$ dnia 6 grudnia $2006 \mathrm{r}$. o zasadach prowadzenia polityki rozwoju (tj. Dz. U. 2021, poz. 1057), w szczególności przepis art. 14 la i 14 lb tejże ustawy. Zgodnie z art. 7aa ustawy o zppr plan rozwojowy to dokument określający reformy i inwestycje z udziałem środków Unii Europejskiej mające na celu łagodzenie społecznych i gospodarczych skutków kryzysu oraz wzmocnienie zrównoważonego rozwoju kraju. 
siębiorczości (w ramach wspierania rozwoju gospodarki) jest uznawane za najszerzej stosowany sposób kierowania procesami gospodarczymi ${ }^{39}$ i służy osiągnięciu celów rozwojowych, w szczególności przy braku skuteczności środków interwencji o charakterze ogólnosystemowym ${ }^{40}$.

Państwo stosuje zróżnicowane sposoby i środki wspierania rozwoju gospodarczego. Są to zarówno świadczenia typu subwencje, dotacje, kredyty, a także zadysponowanie środkami rzeczowymi bądź kapitałem na rzecz przedsiębiorców, jak i rezygnacja przez państwo ze świadczeń od przedsiębiorców, np. ulgi podatkowe. Środki oddziaływania w postaci świadczeń, choć dominujące, to nie wyczerpują katalogu instrumentów wsparcia gospodarczego. Zadania w obszarze wspierania gospodarki należy postrzegać zdecydowanie szerzej, jako modelowanie warunków do rozwoju poprzez ukierunkowane kształtowanie stosunków społeczno-gospodarczych ${ }^{41}$. Ich realizacja przez zobowiązane do tego podmioty (nie tylko organy administracji publicznej) polega na stosowaniu zróżnicowanych prawnych instrumentów wsparcia wynikających z wielu aktów prawnych kwalifikowanych do systemu regulacji publicznoprawnych.

Analiza regulacji normatywnych stanowiących źródło realizacji funkcji wspierania rozwoju gospodarki (w tym przedsiębiorczości) skłania do przyjęcia stanowiska, że jako podstawową $\mathrm{w}$ tym obszarze należy wskazać Ustawę $\mathrm{z}$ dnia 6 marca 2018 roku - Prawo przedsiębiorcó ${ }^{42}$. Jest to ustawa uchwalona w ramach pakietu ustaw dotyczących szeroko ujmowanej „przedsiębiorczości”, a określanego w strategicznych dokumentach rządowych z zakresu rozwoju jako „konstytucja dla bizne-

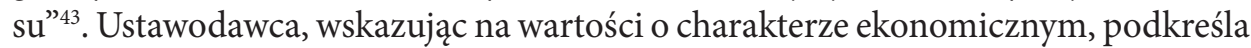
konieczność podejmowania działań ukierunkowanych na rozwój działalności go-

\footnotetext{
${ }^{39}$ Zob. M. Szydło, Regulacja sektorów infrastrukturalnych jako rodzaj funkcji państwa wobec gospodarki, Warszawa 2005, s. 33.

${ }^{40}$ K. Loader, Supporting SMEs through Government Purchasing Activity, „The International Journal of Entrepreneurship and Innovation" 2005, vol. 6, iss. 1, s. 17-26.

${ }^{41}$ Zob. K. Kokocińska, Wspieranie rozwoju działalności gospodarczej w ujęciu zasad i wartości, „Ruch Prawniczy, Ekonomiczny i Socjologiczny" 2018, z. 4.

${ }^{42}$ T.j.: Dz. U. 2021 poz. 162; Ustawa z dnia 6 marca 2018 roku o Centralnej Ewidencji i Informacji o Działalności Gospodarczej i Punkcie Informacji dla Przedsiębiorcy, t.j.: Dz. U. 2020 poz. 2296, 2320; Ustawa z dnia 6 marca 2018 roku o Rzeczniku Małych i Średnich Przedsiębiorców, Dz. U. 2018 poz. 648; Ustawa z dnia 6 marca 2018 roku o zasadach uczestnictwa przedsiębiorców zagranicznych i innych osób zagranicznych w obrocie gospodarczym na terytorium RP, t.j.: Dz. U. 2020 poz. 1252, 2255.

${ }^{43}$ Aktualne cele, których osiągnięcie jest konieczne z punktu widzenia założeń rozwoju kraju, zostały określone w Strategii na rzecz Odpowiedzialnego Rozwoju do roku 2020 (z perspektywą do roku 2030). Strategia ta zakłada między innymi, że zmiany ustawodawcze stanowić mają jeden z podstawowych elementów przebudowy i reformy instytucjonalnej otoczenia przedsiębiorców. Akcentowana w strategii potrzeba zwiększenia odpowiedzialności instytucji państwa za kształtowanie procesów gospodarczych, społecznych i terytorialnych przy zachowaniu konstytucyjnego modelu społecznej gospodarki rynkowej ma uzasadniać aktywność państwa w kreowaniu warunków dla rozwoju (w podejmowaniu działań służących wspieraniu wzrostu gospodarczego); Uchwała numer 8 Rady Ministrów z dnia 14 lutego 2017 r. w sprawie przyjęcia Strategii SOR do roku 2020 (z perspektywą do 2030 r.), dalej także SOR.
} 
spodarczej ${ }^{44}, w$ tym poprzez zapewnienie rozwoju działalności w warunkach wolnej konkurencji, kierując się konstytucyjną zasadą wolności gospodarczej. Ustawa Prawo przedsiębiorców nie zawiera wprost wyrażonego zobowiązania organów administracji publicznej do prowadzenia działań na rzecz wspierania przedsiębiorczości ${ }^{45}$. Jednak wobec tak wyznaczonego celu regulacji, którym jest „rozwój działalności gospodarczej", należy przyjąć, że wszelkie działania organów administracji publicznej objęte regulacją ustawy Prawo przedsiębiorców powinny być wykonywane z uwzględnieniem zapewnienia ciągłego rozwoju działalności gospodarczej. Odnosi się to do jej bardzo zróżnicowanej co do zakresu i form aktywności w procedurze ewidencjonowania działalności gospodarczej, realizacji kompetencji związanych z reglamentacją działalności gospodarczej, koncesjonowaniem czy aktywnością Rzecznika MŚP ${ }^{46}$. Tym samym ustawodawca wskazał kierunek wykładni przepisów ustawowych z zakresu przedsiębiorczości ${ }^{47}$. Przepis prawny tak skonstruowany stanowi normę interpretacyjną dla organów władzy publicznej kształtujących stosunki gospodarcze.

Wyrazem tej koncepcji określania sposobu działania organów administracji publicznej na rzecz rozwoju działalności gospodarczej poprzez osadzanie jej

${ }^{44}$ Preambuła Prawa przedsiębiorców w brzmieniu: „Kierując się konstytucyjną zasadą wolności działalności gospodarczej, a także innymi zasadami konstytucyjnymi mającymi znaczenie dla przedsiębiorców i wykonywanej przez nich działalności gospodarczej, w tym zasadami praworządności, pewności prawa, niedyskryminacji oraz zrównoważonego rozwoju, uznając, że ochrona i wspieranie wolności działalności gospodarczej przyczyniają się do rozwoju gospodarki oraz do wzrostu dobrobytu społecznego, dążąc do zagwarantowania praw przedsiębiorców oraz uwzględniając potrzebę zapewnienia ciągłego rozwoju działalności gospodarczej w warunkach wolnej konkurencji, uchwala się, co następuje: [...]”. Ustawa z dnia 6 marca 2018 roku - Prawo przedsiębiorców, dalej PP.

${ }^{45} \mathrm{~W}$ dotychczasowych regulacjach z zakresu przedsiębiorczości zadaniom organów administracji publicznej poświęcono odrębne przepisy. Na przykład w ustawie Prawo działalności gospodarczej (dalej Pdg) zagadnieniom tym poświęcony był oddzielny rozdział 8 „Zadania organów administracji rządowej i jednostek samorządu terytorialnego w zakresie działalności gospodarczej” obejmujący zadania określone jako wspieranie działalności gospodarczej oraz zadania szczegółowe, kierowane wyłącznie do organów jednostek samorządu terytorialnego. Z kolei w ustawie o swobodzie działalności gospodarczej (dalej sdg) ustawodawca zrezygnował $\mathrm{z}$ wyodrębnienia zadań w osobnym rozdziale, określając je przedmiotowo $\mathrm{w}$ art. 1 jako zadania w zakresie podejmowania, wykonywania i zakończenia działalności gospodarczej, a umiejscowił je w poszczególnych rozdziałach ustawy. Szczególne znaczenie z punktu widzenia poruszanej problematyki miał przepis art. 8 ustawy sdg, który wprost odnosił się do zadania ustawowo określonego jako wspieranie przedsiębiorczości. Zob. na ten temat w szczególności: T. Rabska, Zadania administracji publicznej w dziatalności gospodarczej (problem zakresu obowiązywania prawa działalności gospodarczej), „Ruch Prawniczy, Ekonomiczny i Socjologiczny” 2002, z. 2, s. 138; a także K. Kokocińska, Prawne aspekty wspierania rozwoju przedsiębiorczości - ustawa o swobodzie działalności gospodarczej oraz ustawy ustrojowo-kompetencyjne, „Ruch Prawniczy, Ekonomiczny i Socjologiczny” 2005, z. 4, s. 37; B. Popowska, Wspieranie małych i średnich przedsiębiorców - charakterystyka przepisów Prawa działalności gospodarczej i ich realizacja, „Ruch Prawniczy, Ekonomiczny i Socjologiczny" 2002, z. 2, s. 125 i nast.

${ }^{46} \mathrm{Na}$ ten temat: P. Lissoń, Rzecznik Małych i Średnich Przedsiębiorców: ombudsman czy organ administracji rzadowej? „Ruch Prawniczy, Ekonomiczny i Socjologiczny” 2018, z. 4.

${ }^{47} \mathrm{Na}$ ten temat zob. m.in.: A. Żywicka, L. Bielecki, Załatwianie spraw przedsiębiorców przez administrację publiczna, Warszawa 2020. 
obowiązków w konstytucyjnie określonym systemie wartości jest wprowadzenie ustawowego katalogu zasad postępowania organów administracji publicznej w relacjach $\mathrm{z}$ przedsiębiorcami ${ }^{48}$. Zasady te mają wymiar uniwersalny i odnoszą się do wszelkich stosunków związanych z podejmowaniem, wykonywaniem i zakończeniem działalności gospodarczej ${ }^{49}$, a zaliczyć do nich należy: zasadę wolności działalności gospodarczej (art. 2 PP), zasadę: co nie jest prawem zabronione, jest dozwolone (art. $8 \mathrm{PP}$ ), zasadę wynikającą $\mathrm{z}$ art. 9 tejże ustawy wprowadzającą obowiązek wykonywania działalności gospodarczej zgodnie z zasadami uczciwej konkurencji i poszanowania dobrych obyczajów oraz słusznych interesów innych przedsiębiorców i konsumentów, zasadę domniemania uczciwości przedsiębiorcy (art. 10 ust. $1 \mathrm{PP}$ ), zasadę rozstrzygania wątpliwości faktycznych na korzyść przedsiębiorcy (art. 10 ust. 2 PP), zasadę przyjaznej interpretacji przepisów (art. $11 \mathrm{PP}$ ), zasadę pogłębiania zaufania, proporcjonalności, bezstronności i równego traktowania (art. 12 PP), zasadę odpowiedzialności urzędników za naruszenie prawa (art. 13 $\mathrm{PP}$ ), zasadę pewności prawa (art. $14 \mathrm{PP}$ ) oraz zasadę udzielania informacji (art. 15 $\mathrm{PP}$ ). Według M. Zdyba zasady te wskazują fundamenty ładu publicznego i ładu gospodarczego opierającego się na aksjologicznych podstawach, których źródłem jest Konstytucja $\mathrm{RP}^{50}$, a więc powinny być uwzględniane w procesie stanowienia i stosowania prawa.

Zgodnie $\mathrm{z}$ art. 16 ustawy Prawo przedsiębiorców na straży ich praw, zatem również na straży przestrzegania wskazanych powyżej zasad, stoi Rzecznik Małych i Średnich Przedsiębiorców. Realizowane przez niego zadania określone przepisami Ustawy z dnia 6 marca 2018 roku o Rzeczniku Małych i Średnich Przedsiębiorców należy odnieść także do wartości ujętych w preambule ustawy Prawo przedsiębiorców, w której podkreśla się konieczność zagwarantowania praw przedsiębiorców, uwzględniając potrzebę zapewnienia ciągłego rozwoju działalności gospodarczej w warunkach wolnej konkurencji ${ }^{51}$. Ustawodawca powierzył Rzecznikowi MŚP szczególny typ zadań związanych ze „staniem na straży praw”52, co należy odczy-

${ }^{48}$ Szerzej: K. Kokocińska, Wspieranie rozwoju..., B. Popowska, Zasady postępowania $w$ sprawach z zakresu działalności gospodarczej unormowane w ustawie Prawo przedsiębiorców, „Ruch Prawniczy, Ekonomiczny i Socjologiczny" 2018, z. 4.

${ }^{49}$ Według A. Powałowskiego zasady te nawiązują do konstytucyjnej zasady społecznej gospodarki rynkowej, do której to ustrojowej zasady ustawa Prawo przedsiębiorców (mimo jej znaczenia) nie odwołuje się wprost. A. Powałowski, Nowe prawo przedsiębiorców i ich działalności gospodarczej na tle zasady społecznej gospodarki rynkowej, w: Sektory infrastrukturalne, red. M. Królikowska-Olczak, Warszawa 2018, s. 129.

${ }^{50}$ M. Zdyb, Podstawowe zasady (standardy) ładu gospodarczego w świetle ustawy z 6.3.2018 r. Prawo przedsiębiorców, w: Ustawa z 6.3.2018 r. - Prawo przedsiębiorców - analiza i ocena najważniejszych przepisów, red. M. Sieradzka, dodatek MoP 13/2018, s. 12.

${ }^{51}$ Szerzej: K. Kokocińska, Wspieranie rozwoju ..., s. 48.

${ }^{52}$ P. Lissoń dokonuje następującej klasyfikacji zadań Rzecznika MŚP: „1) podejmowanie interwencji w indywidulanych sprawach mikro, małych i średnich przedsiębiorców, 2) podejmowanie działań na rzecz jednolitej wykładni przepisów prawnych dotyczących działalności gospodarczej, 3) podejmowanie działań na rzecz poprawy stanu prawa gospodarczego, 4) podejmowanie działań na rzecz poprawy praktyki 
tywać jako podejmowanie działań służących ochronie praw przedsiębiorców w relacjach z organami władzy publicznej, a także kształtowaniu i poprawie warunków podejmowania i prowadzenia działalności gospodarczej ${ }^{53}$. Wprowadzenie do polskiego systemu instytucji Rzecznika MŚP stanowi element przebudowy i reformy instytucjonalnej otoczenia przedsiębiorców jako wynik realizacji Strategii na rzecz odpowiedzialnego rozwoju wskazującej na potrzebę zwiększenia odpowiedzialności instytucji państwa za kształtowanie procesów gospodarczych, społecznych i terytorialnych, przy zachowaniu konstytucyjnego modelu społecznej gospodarki rynkowej ${ }^{54}$.

Wśród środków wspierania rozwoju przedsiębiorczości należy wskazać wynikający z przepisu art. 66 ustawy Prawo przedsiębiorców postulat „poprawnej legislacji”. Ustawodawca zdecydował się na wprowadzenie do systemu powszechnie obowiązujących norm prawnych zasad dotyczących tworzenia prawa związanego z podejmowaniem, wykonywaniem i zakończeniem działalności gospodarczej, $\mathrm{w}$ tym na przygotowywanie ocen skutków regulacji. Przepis ten realizuje także postulat ustawodawcy racjonalnego, działającego w przekonaniu o konieczności wprowadzenia określonych środków prawnych. Ma temu służyć obowiązek sporządzania ocen skutków regulacji do projektów aktów prawnych oraz ocen funkcjonowania przepisów prawa, ze szczególnym uwzględnieniem otoczenia prawnego determinującego warunki podejmowania i wykonywania działalności gospodarczej w sektorze mikro-, małych i średnich przedsiębiorców. Zapewnić one powinny możliwie pełną i wiarygodną informację na temat celowości interwencji państwa oraz korzyści i kosztów związanych z podjęciem konkretnych działań, z uwzględnieniem $\mathrm{w}$ procesie stanowienia prawa specyfiki regulacji w obszarze podejmowania, wykonywania i zakończenia działalności gospodarczej w sektorze MŚP.

Wspieranie rozwoju działalności gospodarczej nie jest zadaniem nowym. Działania na rzecz rozwoju przedsiębiorczości od okresu transformacji gospodarczej były przedmiotem zainteresowania ustawodawcy krajowego. Poza ogólnymi przepisami dotyczącymi zadań państwa na rzecz przedsiębiorczości (ustawa Pdg i ustawy sdg) obowiązywały (i obowiązują) regulacje szczegółowe. Wśród nich można wskazać ustawę z dnia 20 października 1994 roku o specjalnych strefach ekonomicznych ${ }^{55}$, której celem było pobudzenie rozwoju społeczno-gospodarczego kraju poprzez stworzenie zachęt podatkowych dla inwestorów (głównie zagranicznych), czy ustawę z dnia 10 maja 2018 roku o wspieraniu nowych inwestycji ${ }^{56}$ będącą kontynuacją

\footnotetext{
funkcjonowania organów, organizacji oraz instytucji publicznych w sprawach mikro, małych i średnich przedsiębiorstw oraz 5) propagowanie wiedzy na temat prawa gospodarczego oraz przedsiębiorczości", P. Lissoń, Rzecznik Małych i Średnich Przedsiębiorców..., s. 58.

${ }^{53}$ Konstytucja biznesu. Komentarz, red. M. Wierzbowski, Warszawa 2019, s. 486.

${ }^{54}$ Uchwała numer 8 Rady Ministrów z dnia 14 lutego $2017 \mathrm{r}$.

${ }^{55}$ T.j.: Dz. U. 2017 poz. 1010 ze zm.

${ }^{56}$ Dz. U. 2018 poz. 115.
} 
wspierania inwestycji poprzez stosowanie zachęt podatkowych dla przedsiębiorców dostępnych na terenie całego kraju, bez ograniczeń terytorialnych. Do tej grupy środków oddziaływania o charakterze wspierającym należy zaliczyć instrumenty prawne wynikające z ustawy z dnia 30 maja 2008 roku o niektórych formach wspierania działalności innowacyjnej ${ }^{57}$. Ustawa ta, kształtując zasady wspierania działalności innowacyjnej, obejmuje regulacją procedury udzielania kredytu technologicznego przez banki kredytujące i premii technologicznej przez Bank Gospodarstwa Krajowego, nadawanie przedsiębiorcy statusu centrum badawczo-rozwojowego oraz pomoc udzielaną $\mathrm{w}$ ramach programów $\mathrm{w}$ obszarze innowacyjności gospodarki, ustanawianych przez ministra właściwego do spraw gospodarki.

Oprócz wprowadzenia do polskiego porządku prawnego regulacji prawnych określających szczegółowe instrumenty prawne wsparcia rozwoju przedsiębiorczości ustawodawca zdecydował się na przeprowadzenie reformy struktur organizacyjnych odpowiedzialnych za realizację zadań w tym obszarze. Założeniem przyjętych regulacji normatywnych była podkreślana konieczność „uregulowania zasad i wzmocnienie współpracy między głównymi instytucjami państwa realizującymi działania na rzecz rozwoju gospodarczego i społecznego, stosując instrumenty ekonomiczne, oraz przez inną obecność na rynku krajowym i rynkach zagranicznych. Realizacji powyższego celu będzie służyło przyjęcie mechanizmów zapewniających koordynację i wzajemne uzupełnianie się podmiotów [...]"58. Zaproponowane rozwiązania, określone przepisami ustawy z dnia 4 lipca 2019 roku o systemie instytucji rozwoju ${ }^{59}$, realizują politykę państwa wyrażoną w $\mathrm{SOR}^{60}$, w której to strategii zapowiedziane zostało utworzenie Polskiego Funduszu Rozwoju (PFR) oraz Grupy PFR. „System instytucji rozwoju” tworzą: Polski Fundusz Rozwoju, Bank Gospodarstwa Krajowego, Polska Agencja Rozwoju Przedsiębiorczości, Korporacja Ubezpieczeń Kredytów Eksportowych Spółka Akcyjna, Polska Agencja Inwestycji i Handlu Spółka Akcyjna, Agencja Rozwoju Przemysłu Spółka Akcyjna. Są to struktury organizacyjne powołane do realizacji celów polityki gospodarczej rządu i rządowych programów gospodarczych, określane wspólnie w SOR jako tzw. Grupa PFR, dysponujące środkami publicznymi przeznaczonymi na realizację wsparcia przedsiębiorców ${ }^{61}$. Szczególne miejsce wśród wskazanych podmiotów

${ }^{57}$ T.j.: Dz. U. 2018 poz. 141 ze zm.

${ }^{58} \mathrm{Z}$ uzasadnienia do projektu ustawy, druk 3479, s. 1.

${ }^{59}$ Dz. U. 2019 poz. 1572.

${ }^{60} \mathrm{Na}$ przykład w Strategii na rzecz Odpowiedzialnego Rozwoju do roku 2020 (z perspektywą do 2030 roku) polski rząd wskazał wśród kierunków interwencji „Zwiększenie koordynacji wsparcia inwestycji rozwojowych". Ma to nastąpić poprzez wprowadzenie zmian instytucjonalnych ukierunkowanych na lepszą koordynację działań podmiotów realizujących politykę gospodarczą w zakresie wsparcia inwestycji rozwojowych, która służyć ma również eliminacji dublowania się ich kompetencji, oraz zwiększenie ich efektywności poprzez łączenie poszczególnych funkcji. SOR, s. 126.

${ }^{61}$ Szerzej: K. Kokocińska, Państwo administracji, w: Niepomijalność administracji, red. T. Kocowski, P. Lissowski, „Acta Universitatis Wratislaviensis” 2020, nr 4, s. 147-161. 
zajmuje Polska Agencja Rozwoju Przedsiębiorczości (PARP) ${ }^{62}$, której celem jest realizacja programów rozwoju gospodarki wspierających działalność innowacyjną i badawczą małych i średnich przedsiębiorstw, rozwój regionalny, wzrost eksportu, rozwój zasobów ludzkich oraz wykorzystywanie nowych technologii w działalności gospodarczej. Zadania te PARP realizuje w szczególności przez świadczenie usług doradczych, organizowanie szkoleń i seminariów, organizowanie przedsięwzięć informacyjnych, promocyjnych, targowych i wystawienniczych w kraju, organizowanie, $w$ porozumieniu $z$ właściwymi instytucjami, przedsięwzięć informacyjnych i promocyjnych za granicą, opracowywanie, wydawanie i rozpowszechnianie publikacji, świadczenie usług eksperckich, w tym organom administracji rządowej i organom jednostek samorządu terytorialnego, prowadzenie rejestru podmiotów „usług rozwojowych”, a przede wszystkim poprzez udzielanie pomocy finansowej przeznaczonej dla MŚP ${ }^{63}$.

\section{Podsumowanie}

Wyznaczanie celów rozwoju społeczno-gospodarczego stanowi zasadniczy przejaw aktywności instytucji unijnych i organów krajowych w kształtowaniu gospodarki ${ }^{64}$. Stosując pośrednie i bezpośrednie środki odziaływania, władza publiczna ukierunkowuje aktywność uczestników rynku na osiąganie przyjętych celów i priorytetów rozwoju, determinuje ich zachowania. Wpływa na decyzje uczestników życia gospodarczego odpowiednio ukształtowanymi instrumentami prawnymi, które mają ostatecznie służyć realizacji przyjętej polityki.

Wprowadzając środki o charakterze wspierającym, determinowane celami przyjętej polityki rozwoju, organy władzy publicznej powinny jednak zmierzać do utrzymywania równowagi pomiędzy mechanizmami konkurencji kształtującymi porządek gospodarczy a działaniami o charakterze interwencyjnym, które mogą go zniekształcić. Dopuszczalność i zakres ingerencji należy oceniać także przez pryzmat realizacji podstawowych praw i wolności gospodarczych. Respektowanie konstytucyjnych, gospodarczych praw podmiotowych (wynikających z unijnego i krajowego porządku prawnego), proporcjonalność stosowanych środków prawnych do przyjętego celu, przestrzeganie podstawowych zasad społecznej gospodarki rynkowej, powinny stanowić o kierunkach zmian przyjmowanego ustawodawstwa.

${ }^{62}$ Ustawa z dnia 9 listopada 2000 r. o utworzeniu Polskiej Agencji Rozwoju Przedsiębiorczości, t.j.: Dz. U. 2020 poz. 299.

${ }^{63}$ Na ten temat szerzej: K. Kokocińska, A. Trela, Polska Agencja Rozwoju Przedsiębiorczości. Status prawny, zakres i charakter prawny zadań, w: Prawo i administracja, t. 4, red. R. Budzinowski, Piła 2005, s. 283-295; tychże: Wspieranie przedsiębiorczości jako zadanie administracji publicznej, w: Prawo wobec wyzwań współczesności, t. 3, red. P. Wiliński, O. Krajniak, B. Guzik, Poznań 2006, s. 71-80.

${ }^{64}$ Zob. K. Strzyczkowski na temat funkcji kierownictwa gospodarczego, Prawo gospodarcze..., s. 175. 
Unia Europejska, akcentując konieczność poprawy środowiska naturalnego i wspieranie postępu naukowo-technicznego, podkreśla potencjał sektora MŚP. Zdiagnozowane bariery rozwoju drobnej przedsiębiorczości, w tym administracyjne i prawne, mogą być ograniczeniem $w$ realizowaniu unijnych strategii na rzecz zielonej i innowacyjnej aktywności przedsiębiorców ${ }^{65}$. Analiza unijnych i krajowych celów polityki na rzecz rozwoju przedsiębiorczości wskazuje, że przyjmowane regulacje prawne zmierzają do pobudzenia przedsiębiorczości, wzmocnienia pozycji przedsiębiorców, stymulując je jednocześnie do osiągania celów publicznych. Wdrażane rozwiązania na poziomie krajowym (w tym o charakterze normatywnym) powinny być wynikiem spójnej, skoordynowanej polityki rozwoju społeczno-gospodarczego. Osiąganie jej celów wymaga jednak przyjmowania i stosowania rozwiązań ogólnosystemowych, uwzględniających wskazane powyżej uwarunkowania, z drugiej zaś strony stosowania instrumentów, które nie będą stanowiły zagrożeń dla prawidłowości funkcjonowania gospodarki rynkowej.

Analiza prawnych instrumentów na rzecz rozwoju MŚP skłania do refleksji nad sposobem wdrażania unijnej polityki na rzecz osiągania celów zielonego ładu (w kontekście jednolitego rynku cyfrowego). Polski ustawodawca, podejmując kolejną próbę wdrożenia systemowych rozwiązań odnoszących się do podejmowania, prowadzenia i zakończenia działalności gospodarczej na terytorium RP, koncentruje się przede wszystkim na środkach prawnych służących rozwojowi działalności gospodarczej. Oprócz wprowadzenia zasad - postulatów wyznaczających relacje w stosunkach zachodzących pomiędzy organem administracji publicznej a przedsiębiorcami - istotne są zmiany dotyczące zmniejszenia obciążeń publicznoprawnych, wprowadzenia uproszczeń związanych z podejmowaniem działalności, a także $\mathrm{w}$ toku jej prowadzenia ${ }^{66}$. Przyjęta polityka państwa na rzecz rozwoju przedsiębiorczości wywołuje także określone przeobrażenia zachodzące w strukturach administracji publicznej, które są nieodłącznym elementem przemian gospodarczych i społecznych. W przypadku aktywności na rzecz wspierania MŚP (także w kontekście osiągania celów zielonego ładu) na uwagę zasługuje działalność instytucji rozwoju, których zadania publiczne wpisują się w politykę na rzecz wsparcia sektora MŚP.

Analiza przepisów prawa z zakresu przedsiębiorczości potwierdza, że nadal przedsiębiorcy napotykają liczne bariery, w szczególności w obszarze regulacji prawnych związanych z wdrażaniem nowoczesnych technologii oraz własności intelektualnej. Brak jest kompleksowych rozwiązań zachęcających MŚP do aktywnego uczestnictwa w takich obszarach jak badania naukowe i innowacje ${ }^{67}$, gospodarka

${ }^{65}$ S. Novero, Impact analysis of public policies supporting SMEs' technological innovation: An Italian case, „International Journal of Technology, Policy and Management” 2011, nr 11(1), s. 34-56.

${ }^{66}$ Zob. np.: Rozdział 5. Ograniczenia kontroli przedsiębiorców ustawy Prawo przedsiębiorców.

${ }^{67}$ D.C. Moura, M.J. Madeira, F.A.P. Duarte, J. Carvalho, O. Kahilana, Absorptive capacity and cooperation evidence in innovation from public policies for innovation, „International Journal of Innovation Science” 2020, vol. 11, no. 1, s. 2-19. 
niskoemisyjna oraz technologie informacyjne i komunikacyjne. Rolą władz publicznych jest podejmowane działań, także poprzez wszechstronne przepisy prawa, które będą służyć budowaniu bardziej przyjaznego środowiska funkcjonowania MŚP.

\section{Resumen extenso / Streszczenie}

Establecimiento de las prioridades para el desarrollo socioeconómico como determinante objetiva de la actividad de las entidades del sector de las pymes (enfoque de derecho público)

El papel del derecho en el espacio económico está determinado por el sistema económico vigente, que constituye el resultado de las normas, principios y valores adoptados que determinan la intensidad admisible de la influencia del poder público en las relaciones socioeconómicas. El derecho es un instrumento para la realización de los objetivos sociales y económicos adoptados y determinados por los organismos de las autoridades públicas que realizan la política (política estatal) a favor del desarrollo. Sobre todo, sirve para crear las condiciones propicias para el funcionamiento de una economía de mercado competitiva y moderna.

El marco legal, que garantiza los derechos y libertades económicas básicas, se llena cada vez más de actividades que motivan a las personas a realizar determinados comportamientos, complementando y a menudo sustituyendo los mecanismos de libre competencia. Esta situación se justifica por la necesidad de alcanzar importantes objetivos públicos resultantes de la actual política pública, realizada a nivel de la UE o a nivel nacional. Los instrumentos legales de apoyo (motivadores) crean un conjunto de incentivos para la realización de actividades específicas por parte de los empresarios, conformes con la política de desarrollo socioeconómico del Estado. En consecuencia, el Estado (en un ámbito más amplio, la Unión Europea) estimula a los participantes en el mercado mediante diversos instrumentos legales para lograr los objetivos socioeconómicos adoptados. Sin embargo, estas acciones (lo que se refiere también a la política de las autoridades públicas) no deben dar lugar a la modificación de las relaciones socioeconómicas del sistema económico establecido, que está construido por las normas del tratado y las normas constitucionales. Estas acciones deben inscribirse en el contexto socioeconómico actual, que está determinado no solo por las libertades y los derechos económicos garantizados, sino también por los principios constitucionales del sistema socioeconómico, y en particular por el principio de "economía social de mercado" que define el sistema económico de la Unión Europea, así como el modelo económico nacional.

Las necesidades sociales y económicas, determinadas por los objetivos de la política socioeconómica de la UE y de los Estados miembros, se expresan en los actos políticos del poder ejecutivo - estrategias de desarrollo, planes y programas - adop- 
tados periódicamente (en una perspectiva temporal concreta). Los actos adoptados de la política socioeconómica indican, entre otros, los objetivos y las prioridades de las acciones, así como el grado y las direcciones de la injerencia estatal en el ámbito del desarrollo y la cohesión, constituyendo no sólo una expresión de las direcciones de las reformas, sino también un punto de referencia para la actividad de los organismos de la administración pública responsables de la ejecución de la política de desarrollo. En la época de la europeización, los objetivos de la política nacional constituyen una expresión de las direcciones generales de las transformaciones socioeconómicas, resultantes de las ideas y conceptos actuales que conciernen a la economía y la vida social, realizados hoy en día a escala mundial. La planificación de las acciones de las autoridades públicas, que deben encontrar su referencia en las regulaciones normativas, asegura tanto la estabilidad de las relaciones socioeconómicas como la seguridad a los participantes de las operaciones económicas.

Los supuestos de la dimensión social y económica del mercado único de la Unión Europea, cuya esencia se basa en el crecimiento sostenible, en una economía social de mercado altamente competitiva, orientada al pleno empleo y al progreso social, y en un alto nivel de protección y mejora de la calidad del medio ambiente, encuentran su referente en una visión contemporánea de Europa. Europa inicia el proceso de transición que lleva hacia la neutralidad climática y el liderazgo digital. La Nueva Estrategia Industrial para Europa adoptada, que asume una transformación ecológica y digital, cuyo ámbito de implementación y la naturaleza de las acciones previstas constituye una ejecución consistente de la política de la UE definida en el Programa Estratégico del Consejo Europeo para los años 2019-2024. El Pacto Verde Europeo y la estrategia "Configurar el futuro digital de Europa" indican los objetivos y la dirección del cambio de la nueva política industrial, centrada en la solución de los problemas climáticos y medioambientales. Esta política se basa en un sólido fundamento de los valores de la economía social de mercado europea: competencia, mercados abiertos, un alto nivel de investigación y tecnología, y un mercado único fuerte que elimina las barreras y reduce la burocracia. Entre los elementos básicos de la transformación industrial de Europa, como el apoyo a la industria para pasar a la neutralidad climática, la construcción de una economía de circuito cerrado, se subraya la necesidad de crear seguridad para la industria, es decir, construir un mercado único profundo y más digital. Los objetivos básicos incluyen la preparación de un plan de acción concerniente a la ejecución de las disposiciones del mercado único de la propiedad intelectual, la revisión y la adaptación de las normas de competencia de la UE y la adaptación de regulaciones legales respecto a los servicios digitales para actualizar y reforzar el marco legal del mercado único de los servicios digitales. Con el fin de poner en práctica estas medidas, es necesario tener en concideración la importancia del sector de las pymes, que se refleja en el enfoque de las instituciones de la UE "pymes para pymes". Destacando la importancia de las pymes de alta tecnología que pueden ayudar a los grandes 
empresarios a adaptar sus modelos de negocio e introducir nuevas formas de trabajo adecuadas a la era digital, la Unión Europea apoya a las empresas tipo start-up en la construcción de la economía de plataformas. Esto se refleja en "Una Estrategia de las pymes en pro de una Europa sostenible y digital", adoptada en marzo de 2020, que constituye uno de los elementos clave de la política de la Unión Europea a favor del desarrollo socioeconómico. Sin embargo, aparte de los objetivos de la política de la UE a favor del desarrollo de las pymes, el espacio determinado por los supuestos de la política económica de la Unión Europea, deben completar las acciones que se reflejan en los actos normativos. Por lo tanto, es importante determinar con qué medios legales de la política de desarrollo socioeconómico tanto las instituciones UE como las nacionales logran los objetivos aceptados. Asimismo, es importante la eficacia de las acciones emprendidas.

Conforme con la actitud iniciada por la Comisión Europea en 2008, uno de los objetivos clave realizados en los últimos años es crear las condiciones para que las pymes se adapten a los retos relacionados con la protección de medio ambiente y al funcionamiento del mercado único digital, mejorando el acceso a la financiación. Esto supone un apoyo crucial para que las pymes puedan hacer frente a los retos de la globalización y el cambio climático. En la Comunicación de la Comisión al Parlamento Europeo, al Consejo, al Comité Económico y Social Europeo y al Comité de las Regiones: Plan de Acción para el Emprendimiento hasta el año 2020 - Fomentar la mentalidad empresarial en Europa 2013. Uno de los pilares, dentro de los objetivos definidos de la política de la UE, es la creación de un entorno empresarial que requiere instrumentos legales adecuados. Gracias a ellos, tanto las instituciones de la UE como los Estados miembros (organismos de las administraciones públicas) ingieren en los procesos económicos para alcanzar los objetivos socioeconómicos definidos en los ámbitos clave en cuanto a los resultados adoptados. En el caso de las pymes, el ámbito en el que es imprescindible iniciar acciones con el fin de eliminar los obstáculos existentes para la creación y el crecimiento de estas empresas es la apertura de nuevas oportunidades de negocio en la era digital, mediante un mejor uso de las tecnologías de la información y la comunicación (TIC), que constituyen una fuente clave de crecimiento para la economía nacional.

El análisis realizado muestra que el Estado utiliza diversas formas y medios para apoyar el desarrollo económico. Se trata tanto de prestaciones como subvenciones, ayudas, préstamos y disposición de medios físicos o capital en beneficio de los empresarios, como de la renuncia por parte del Estado de las prestaciones de los empresarios, por ejemplo, las desgravaciones fiscales. Las medidas de influencia en forma de prestaciones, aunque dominantes, no agotan el catálogo de instrumentos de apoyo económico. Las tareas en el ámbito del apoyo económico deben percibirse de forma mucho más amplia, como la modelización de las condiciones para el desarrollo a través de la configuración específica de las relaciones socioeconómicas. Su ejecución por parte de las entidades obligadas a ello (no sólo los organismos 
de la administración pública) consiste en la utilización de diversos instrumentos legales de apoyo resultantes de numerosos actos jurídicos calificados en el sistema de las normas de derecho público.

Introduciendo medidas de apoyo, determinadas por los objetivos de la política de desarrollo adoptada, los organismos de las autoridades públicas deben procurar mantener el equilibrio entre los mecanismos de competencia que configuran el orden económico y las actividades de carácter intervencionista que pueden distorsionarlo. La admisibilidad y el alcance de la injerencia deben evaluarse también desde la perspectiva de la realización de los derechos y libertades económicas fundamentales. El respeto de los derechos subjetivos constitucionales y económicos (resultantes del ordenamiento jurídico de la UE y nacional), la proporcionalidad de las medidas legales aplicadas con respecto al objetivo adoptado y el cumplimiento de los principios básicos de una economía social de mercado deben determinar las direcciones de los cambios en la legislación adoptada.

La Unión Europea, aceptando la necesidad para mejorar el medio ambiente y apoyar el progreso científico y técnico, destaca el potencial del sector de las pymes. Las barreras diagnosticadas para el desarrollo de la pequeña empresa, incluidas las administrativas y legales, pueden constituir una limitación en la ejecución de las estrategias de la UE a favor de la actividad verde e innovadora de los empresarios. El análisis de los objetivos de las políticas de la UE y los objetivos nacionales para el desarrollo de la empresa indica que las normativas legales adoptadas tienen como objetivo fomentar la mentalidad empresarial, reforzar la posición de los empresarios y estimularlos al mismo tiempo para alcanzar los objetivos públicos. Sin embargo, las soluciones implementadas a nivel nacional (incluso de carácter normativo) deben ser el resultado de una política coherente y coordinada de desarrollo socioeconómico. La consecución de sus objetivos requiere, por un lado, la adopción y aplicación de soluciones para todo el sistema que tengan en cuenta las condiciones indicadas en este trabajo y, por otro, la aplicación de instrumentos que no supongan una amenaza para el correcto funcionamiento de la economía de mercado.

El análisis de los instrumentos legales para el desarrollo de las pymes nos lleva a reflexionar sobre la forma de aplicar la política de la UE para lograr los objetivos del Pacto Verde (en el contexto del Mercado Único Digital). Ante todo, el legislador polaco se centra en las medidas legales que sirven para el desarrollo de la actividad empresarial, haciendo un nuevo intento de aplicar soluciones sistémicas relacionadas con la creación, la gestión y el cierre de la actividad económica en el territorio de la República de Polonia (un paquete de leyes denominado Constitución de la Empresa, incluida la Ley de Emprendedores). Aparte de la introducción de los principios - postulados que definen las relaciones entre los organismos de la administración pública y los empresarios - los cambios significativos se refieren a la reducción de las cargas públicas, la introducción de simplificaciones relacionadas con el inicio de la actividad económica, así como en curso de su 
desarrollo. La política estatal adoptada a favor del desarrollo empresarial induce también transformaciones específicas en las estructuras de la administración pública, que son un elemento inherente a los cambios económicos y sociales. En el caso de las actividades destinadas a apoyar a las pymes (también en el contexto de la consecución de los objetivos del Pacto Verde), merece atención la actividad de las instituciones de fomento, cuyas tareas públicas están incluidas en la política de apoyo al sector de las pymes.

El análisis de la normativa legal en el ámbito de la iniciativa empresarial confirma que los empresarios siguen encontrando numerosos obstáculos, en particular en el ámbito de la normativa legal relacionada con la aplicación de las tecnologías modernas y la propiedad intelectual. Faltan soluciones complejas que animen a las pymes a participar activamente en ámbitos como la investigación científica y las innovaciones, la economía de bajas emisiones y las tecnologías de la información y la comunicación. El papel de las autoridades públicas es tomar medidas, también a través de una amplia normativa legal, que sirvan para construir un entorno más favorable para el funcionamiento de las pymes.

\section{Bibliografia}

Adamczyk, A., Definicja i istota społecznej gospodarki rynkowej, w: Społeczna gospodarka rynkowa, red. R.W. Włodarczyk, Warszawa 2010.

Banasiński C., Konstytucyjne podstawy porządku prawnego gospodarce, w: Konstytucja. Trybunat Konstytucyjny, red. C. Banasiński, J. Oniszczuk, Warszawa 1998.

Banasiński C., Konstytucyjne podstawy ustroju gospodarczego, w: Prawo gospodarcze. Zagadnienia administracyjnoprawne, wyd. 2, red. H. Gronkiewicz-Waltz, M. Wierzbowski, Warszawa 2011.

Boć J., Konstytucje Rzeczypospolitej oraz komentarz do Konstytucji RP z 1997 roku, Wrocław 1998.

Buzek J., Surdej A., Odrodzenie ducha - budowa wolności. Perspektywa rozwoju gospodarki solidarnej, „Ruch Prawniczy, Ekonomiczny i Socjologiczny” 2010, z. 4.

Communication from the Commission to the European Parliament, the Council, the European Economic and Social Committee and the Committee of the Regions - A New Industrial Strategy for Europe, Brussels, 10.3.2020, COM(2020) 102 final.

Communication from the Commission to the European Parliament, the Council, the European Economic and Social Committee and the Committee of the Regions - The European Green Deal, Brussels, 11.12.2019, $\operatorname{COM}(2019) 640$ final.

Communication from the Commission to the European Parliament, the Council, the European Economic and Social Committee and the Committee of the Regions - Shaping Europe's digital future, Brussels, 19.2.2020, $\operatorname{COM}(2020) 67$ final.

Communication from the Commission to the European Parliament, the Council, the European Economic and Social Committee and the Committee of the Regions - An SME Strategy for a sustainable and digital Europe, Brussels, 10.3.2020, COM(2020) 103 final.

Communication from the Commission Communication from the Commission to the European Parliament, the Council, the European Economic and Social Committee and the Committee of the Regions - EUROPE 2020. A strategy for smart, sustainable and inclusive growth, Brussels 2010, COM (2010) 2020 final. 
Domańska A., Konstytucyjne podstawy ustroju gospodarczego Polski, Warszawa 2001.

Horubski K., $\$ 30$. Wspieranie gospodarki, w: System Prawa Administracyjnego, t. 8A: Publiczne prawo gospodarcze, red. R. Hauser, Z. Niewiadomski, A. Wróbel, Warszawa 2013.

Kiczka K., Funkcje administracji gospodarczej jako przedmiot badań, w: Funkcje wspótczesnej administracji gospodarczej, red. B. Popowska, Poznań 2006.

Kiczka K., Konstytucjonalizacja publicznego prawa gospodarczego, w: Nowe problemy badawcze w teorii publicznego prawa gospodarczego ( $z$ uwzględnieniem samorzadu terytorialnego), red. L. Kieres, Wrocław 2010.

Kiczka K., Uwagi o wolności działalności gospodarczej, w: Księga Jubileuszowa Profesora S. Jędrzejewskiego, Toruń 2009.

Kocowski T., Reglamentacja forma interwencjonizmu państwowego w społecznej gospodarce rynkowej, w: Państwo i rynek. Obszary zawodności, red. U. Kalina-Prasznic, Wrocław 2011.

Kokocińska K., Państwo administracji, w: Niepomijalność administracji, red. T. Kocowski, P. Lissowski, „Acta Universitatis Wratislaviensis” 2020, nr 4, s.147-161.

Kokocińska K., Prawne aspekty wspierania rozwoju przedsiębiorczości - ustawa o swobodzie działalności gospodarczej oraz ustawy ustrojowo-kompetencyjne, „Ruch Prawniczy, Ekonomiczny i Socjologiczny" 2005, z. 4.

Kokocińska K., Prawny mechanizm prowadzenia polityki rozwoju w zdecentralizowanych strukturach władzy publicznej, Poznań 2014.

Kokocińska K., Społeczna gospodarka rynkowa - komplementarność, równowaga czy przewaga wartości? Uwagi na tle działań państwa w zakresie prowadzenia polityki rozwoju, „Gdańskie Studia Prawnicze" 2017, nr 37.

Kokocińska K., Wspieranie rozwoju działalności gospodarczej w ujęciu zasad i wartości, „Ruch Prawniczy, Ekonomiczny i Socjologiczny" 2018, z. 4.

Kokocińska K., Trela A., Polska Agencja Rozwoju Przedsiębiorczości. Status prawny, zakres charakter prawny zadań, w: Prawo i administracja, t. 4, red. R. Budzinowski, Piła 2005.

Kokocińska K., Trela A., Wspieranie przedsiębiorczości jako zadanie administracji publicznej, w: Prawo wobec wyzwań wspótczesności, t. 3, red. P. Wiliński, O. Krajniak, B. Guzik, Poznań 2006.

Komunikat Komisji do Parlamentu Europejskiego, Rady Europejskiej, Rady, Europejskiego Komitetu Ekonomiczno-Społecznego i Komitetu Regionów: Decydujący moment dla Europy: naprawa i przygotowanie na następną generację, COM(2020) 456 final, Bruksela, 27.5.2020.

Komunikat Komisji do Parlamentu Europejskiego, Rady Europejskiej, Rady, Europejskiego Komitetu Ekonomiczno-Społecznego i Komitetu Regionów: Budżet UE napędza plan odbudowy Europy, $\operatorname{COM}(2020) 442$ final, Bruksela, 27.5.2020.

Komunikat Komisji do Parlamentu Europejskiego, Rady, Europejskiego Komitetu Ekonomiczno-Społecznego i Komitetu Regionów - Przegląd programu „Small Business Act” dla Europy KOM(2011) 78 wersja ostateczna, Bruksela, 23.02.2011.

Komunikat Komisji do Parlamentu Europejskiego, Rady, Europejskiego Komitetu Ekonomiczno-Społecznego i Komitetu Regionów: Sprawność regulacyjna UE, COM(2012) 746 final, Bruksela, 12.12.2012.

Komunikat Komisji do Parlamentu Europejskiego, Rady, Europejskiego Komitetu Ekonomiczno-Społecznego i Komitetu Regionów: Inteligentne regulacje - odpowiedź na potrzeby małych i średnich przedsiębiorstw, $\operatorname{COM}(2013) 122$ final, Bruksela, 7.03.2013.

Komunikat Komisji do Parlamentu Europejskiego, Rady, Europejskiego Komitetu Ekonomiczno-Społecznego i Komitetu Regionów: Plan działania na rzecz przedsiębiorczości do 2020 r. Pobudzanie ducha przedsiębiorczości w Europie, COM(2012) 795 finał, Bruksela, 9.01.2013.

Komunikat Komisji do Parlamentu Europejskiego, Rady, Europejskiego Komitetu Ekonomiczno-Społecznego i Komitetu Regionów: „Najpierw myśl na małą skalę” - Program „Small Business Act" dla Europy, KOM(2008) 394 wersja ostateczna, Bruksela, 25.6.2008. 
Komunikat Komisji do Parlamentu Europejskiego, Rady, Europejskiego Komitetu Ekonomiczno-Społecznego i Komitetu Regionów: Czysta planeta dla wszystkich - Europejska długoterminowa wizja strategiczna dobrze prosperującej, nowoczesnej, konkurencyjnej i neutralnej dla klimatu gospodarki, Bruksela, 28.11.2018, COM (2018) 773.

Komunikat Komisji do Parlamentu Europejskiego, Rady, Europejskiego Komitetu Ekonomiczno-Społecznego i Komitetu Regionów: W kierunku odnowy gospodarczej sprzyjającej zatrudnieniu, $\operatorname{COM(2012)~} 173$ final, Bruksela, 18.04.2012.

Konstytucja biznesu. Komentarz, red. M. Wierzbowski, Warszawa 2019.

Kosikowski C., Publiczne prawo gospodarcze Polski i Unii Europejskiej, Warszawa 2007.

Kosikowski C., Zasady ustroju społecznego i gospodarczego, w: Podstawowe problemy stosowania Konstytucji Rzeczypospolitej Polskiej, Raport wstępny, red. K. Działocha, Warszawa 2004

Lissoń P., Rzecznik Małych i Średnich Przedsiębiorców: ombudsman czy organ administracji rządowej? „Ruch Prawniczy, Ekonomiczny i Socjologiczny” 2018, z. 4.

Loader K., Supporting SMEs through Government Purchasing Activity, „The International Journal of Entrepreneurship and Innovation" 2005, vol. 6, iss. 1.

Moura D.C., Madeira M.J., Duarte F.A. P., Carvalho J., Kahilana O., Absorptive capacity and cooperation evidence in innovation from public policies for innovation, „International Journal of Innovation Science" 2020, vol. 11, no. 1, s. 2-19.

Musiałkowska I., Idczak P., How COVID-19 impacted the European integration processes? The case of EU Cohesion Policy and budget, w: Towards the „new normal” after COVID-19-a post-transition economy perspective, red. E. Mińska-Struzik, B. Jankowska, Poznań 2021.

Novero S., Impact analysis of public policies supporting SMEs' technological innovation: an Italian case, „International Journal of Technology, Policy and Management” 2011, nr 11(1).

Popowska B., Wspieranie małych i średnich przedsiębiorców - charakterystyka przepisów Prawa działalności gospodarczej i ich realizacja, „Ruch Prawniczy, Ekonomiczny i Socjologiczny” 2002, z. 2.

Powałowski A., Nowe prawo przedsiębiorców i ich działalności gospodarczej na tle zasady społecznej gospodarki rynkowej, w: Sektory infrastrukturalne, red. M. Królikowska - Olczak, Warszawa 2018.

Prawo gospodarcze. Zagadnienia administracyjnoprawne, red. H. Gronkiewicz-Waltz, M. Wierzbowski, wyd. 2 zm., Warszawa 2011.

Przesławska G., Społeczna gospodarka rynkowa, w: Regulowana gospodarka rynkowa, red. U. Kalina-Prasznic, Kraków 2003.

Publiczne prawo gospodarcze. Zarys wykładu, red. J. Grabowski, Bydgoszcz-Katowice 2008.

Pysz P., Społeczna gospodarka rynkowa. Ordoliberalna koncepcja polityki gospodarczej, Warszawa 2008.

Rabska T., Gospodarka rynkowa i jej zasady, w: Konstytucja i gospodarka, wybór i opracowanie P. Kaczanowski, Warszawa 1995.

Rabska T., Zadania administracji publicznej $w$ działalności gospodarczej (problem zakresu obowiązywania prawa działalności gospodarczej), „Ruch Prawniczy, Ekonomiczny i Socjologiczny” 2002, z. 2.

Radicic D., Pugh G., Hollanders H., Winties R., Fairburn J., The impact of innovation support programs on small and medium enterprises innovation in traditional manufacturing industries: An evaluation for seven European Union regions, „Environment and Planning C: Government and Policy" 2015, nr 34(8).

Rozporządzenie Komisji (UE) nr 651/2014 z dnia 17 czerwca 2014 r. uznającego niektóre rodzaje pomocy za zgodne z rynkiem wewnętrznym w zastosowaniu art. 107 i 108 Traktatu, Dz. Urz. UE L $187 / 1$.

Sanetra W., Prawo pracy po Traktacie z Lizbony, „Europejski Przegląd Sądowy”, luty 2010.

Sobczak K., Gospodarka rynkowa a władza publiczna, Warszawa 1997.

Sobczak K., Gospodarka w ujęciu konstytucyjnym, „Przegląd Ustawodawstwa Gospodarczego” 1997, nr 2.

Strzyczkowski K., Prawo gospodarcze publiczne, wyd. 4, Warszawa 2008. 
Strzyczkowski K., Prawo gospodarcze publiczne, wyd. 6, Warszawa 2011.

Strzyczkowski K., Konstytucyjna zasada społecznej gospodarki rynkowej jako podstawa tworzenia i stosowania prawa, w: Zasady ustroju społecznego i gospodarczego procesie stosowania Konstytucji, red. C. Kosikowski, Warszawa 2005.

A. Szmyt, O normowaniu podstaw ustroju gospodarczego Rzeczypospolitej Polskiej, „Gdańskie Studia Prawnicze", t. 5, 1999.

Szydło M., Regulacja sektorów infrastrukturalnych jako rodzaj funkcji państwa wobec gospodarki, Warszawa 2005.

Traktat o Unii Europejskiej (wersja skonsolidowana), Dz. Urz. UE z 26.10.2012, C 326/13.

Uchwała numer 8 Rady Ministrów z dnia 14 lutego 2017 r. w sprawie przyjęcia Strategii na rzecz Odpowiedzialnego Rozwoju do roku 2020 (z perspektywą do 2030 r.)

Wang Y., What are the biggest obstacles to growth of SMEs in developing countries? - An empirical evidence from an enterprise survey, „Borsa Istanbul Review” 2016, vol. 16, iss. 3, s. 167-176.

Włudyka T., Model społecznej gospodarki rynkowej a transformacja ustrojowa polskiej gospodarki. Analiza prawnogospodarcza, Kraków 2002.

Wniosek. Rozporządzenie Parlamentu Europejskiego i Rady ustanawiające Program InvestEU, COM/2020/403 final, Bruksela, 29.5.2020

Zasady ustroju społecznego i gospodarczego procesie stosowania Konstytucji, red. C. Kosikowski, Warszawa 2005.

Zdyb M., Podstawowe zasady (standardy) ładu gospodarczego w świetle ustawy z 6.3.2018 r. Prawo przedsiębiorców, w: Ustawa z 6.3.2018 r. - Prawo przedsiębiorców - analiza i ocena najważniejszych przepisów, red. M. Sieradzka, dodatek MoP 13/2018.

Zmieniony wniosek Komisji Europejskiej Rozporządzenie Parlamentu Europejskiego i Rady w sprawie ustanowienia ram na potrzeby osiągnięcia neutralności klimatycznej i zmiany rozporządzenia (UE) 2018/1999 (Europejskie prawo o klimacie), Brussels, 17.9.2020, COM(2020) 563 final, 2020/0036 (COD).

Żurawik A., Zasady ogólne publicznego prawa gospodarczego, w: System Prawa Administracyjnego, t. 8A: Publiczne prawo gospodarcze, red. R. Hauser, Z. Niewiadomski, A. Wróbel, Warszawa 2013.

Żywicka A., Bielecki L., Załatwianie spraw przedsiębiorców przez administrację publiczną, Warszawa 2020. 
